\title{
Escherichia coli periplasmic protein FepB binds ferrienterobactin
}

\author{
Daren L. Stephens, Michael D. Choe and Charles F. Earhart \\ Author for correspondence: Charles F. Earhart. Tel: +1512471 1561. Fax: +1 5124717088.
}

Department of

Microbiology, The University of Texas at Austin, Austin, TX 78712-1095, USA

\begin{abstract}
Most high-affinity systems for iron uptake in Gram-negative bacteria are thought to employ periplasmic-binding-protein-dependent transport. In Escherichia coli, FepB is a periplasmic protein required for uptake of iron complexed to its endogenously-synthesized siderophore enterobactin (Ent). Direct evidence that ferrienterobactin (FeEnt) binds to FepB is lacking because high background binding by FeEnt prevents use of the usual binding protein assays. Here the membrane localization vehicle LppOmpA [Francisco, J. A., Earhart, C. F. \& Georgiou, G. (1992). Proc Natl Acad Sci USA 89, 2713-2717] was employed to place FepB in the $E$. coli outer membrane. Plasmid pTX700 was constructed and shown to encode, under lac operator control, the 'tribrid' protein LppOmpAFepB; the carboxy-terminal FepB portion lacks at most two amino acids of mature FepB. After short induction periods, most of the tribrid was in the outer membrane. A number of LppOmpAFepB species could be detected; some were degradation products and some may be related to the multiplicity of FepB forms previously observed in minicells and maxicells. Outer membrane harbouring the tribrid and lacking FepA, the normal outer membrane receptor for FeEnt, bound approximately four times more FeEnt than outer membrane from uninduced cells, from cells lacking pTX700 and from cells expressing only an LppOmpA 'dibrid'. Similarly, whole UT5600( fepA)/pTX700 cells induced for tribrid synthesis bound FeEnt and this binding was not affected by energy poisons. The results demonstrated that FepB can bind FeEnt, thereby definitively placing FeEnt transport in the periplasmic permease category of transport systems, and that the LPpOMPA localization vehicle can be used with periplasmic binding proteins.
\end{abstract}

Keywords: iron assimilation, periplasmic binding protein, enterobactin, outer membrane, fepB

\section{INTRODUCTION}

Escherichia coli obtains iron in iron-deficient environments by synthesizing and secreting the siderophore enterobactin (Ent) (reviewed by Earhart, 1987). Ent, a cyclic trimer of dihydroxybenzoylserine with a molecular mass of $663 \mathrm{Da}$, binds environmental $\mathrm{Fe}$ (III) with high affinity. The ferrienterobactin (FeEnt) complex is then transported into the cytoplasm via a periplasmic permease (ABC importer) transport type system; specifically, the FeEnt system is a member of the iron/ $B_{12}$ subset of permeases that require a TonB-dependent outer membrane receptor in addition to the normal permease components (Shea \& McIntosh, 1991). Periplasmic permeases, a subclass of the

Abbreviations: Ent, enterobactin; FeEnt, ferrienterobactin.
ABC transporter (traffic ATPase) superfamily, typically consist of two distinct integral cytoplasmic membrane proteins, each with six to eight membrane-spanning segments, and two copies of another cytoplasmic membrane polypeptide bearing the characteristic ATP-binding domains (Fath \& Kolter, 1993). In addition, unlike other ABC transporter subclasses, periplasmic permeases require a periplasmic binding protein. For FeEnt uptake, FepA is the outer membrane receptor, FepD and $G$ are the hydrophobic cytoplasmic membrane proteins, the ATPbinding domain is located on FepC, and FepB is the periplasmic protein. The current view of FeEnt import is as follows. Extracellular FeEnt binds to FepA in the outer membrane. FepA, a gated pore (Rutz et al., 1992), opens by means of an electrochemical potential transduced by the TonB protein (Postle, 1993), releasing FeEnt into the periplasm, where it is bound by FepB. FepB, in turn, 
presents FeEnt to the cytoplasmic membrane complex of FepC, D and G which then employs ATP to accomplish passage of FeEnt through the cytoplasmic membrane (Chenault \& Earhart, 1992; Silver \& Walderhaug, 1992). Mutations in any of the five fep genes $(A, B, C, D$ and $G)$ block FeEnt uptake.

The periplasmic substrate-binding protein is the unique feature of bacterial ABC importers (Fath \& Kolter, 1993). These binding proteins, of which there are dozens of different species in E. coli (Furlong, 1987), can be released into the medium by osmotic shock; their absence results in the loss of ability to transport their specific substrates. In all shock-sensitive permeases where definitive experiments have been conducted, the periplasmic component binds its transported solute with high affinity. Several periplasmic binding proteins have been well characterized (Ames, 1986; Quiocho, 1990) and found to share several traits. They are monomeric and unusually stable, have a binding cleft between two similar globular domains and undergo a large conformational change upon binding their ligand. In all systems except those for ironsiderophore complexes and vitamin $\mathrm{B}_{12}$, which have specific outer membrane receptors, they serve as the initial receptor for active transport.

For most substrates transported by periplasmic permeases, binding of the substrate to its cognate periplasmic protein is readily demonstrated by equilibrium dialysis (Guyer et al., 1985; Rosen \& Vasington, 1971) and by filter binding assays (Lever, 1972). Ferrisiderophore uptake is generally by means of periplasmic permease systems in enteric bacteria. However, because of non-specific binding of iron (C. F. Earhart, unpublished results; Koster \& Braun, 1990) in only one case has the putative periplasmic binding protein been shown to bind the appropriate ferrisiderophore complex (Koster \& Braun, 1990). These authors employed a novel whole-cell binding procedure to demonstrate that the periplasmic protein FhuD binds several ironhydroxamate siderophore complexes and showed, in a cell-free system, that the association of such complexes with FhuD rendered it resistant to proteinase $\mathrm{K}$.

The present study was performed to determine if FepB binds FeEnt, as predicted. Our approach was based on the fact that, although binding assays using soluble periplasmic protein fractions are unsatisfatory, binding assays of ferrisiderophore complexes to membrane preparations containing the appropriate receptor are feasible (Ichihara \& Mizushima, 1977; McIntosh et al., 1979; Stoebner et al., 1992). We utilized a procedure whereby exported soluble proteins such as $\beta$-lactamase (Francisco et al., 1992) can be localized to the outer membrane of E. coli. In this system, 'tribrid' proteins are produced which have the soluble exported protein of interest as the carboxy-terminal domain. The amino-terminal domains consist of portions of the major lipoprotein (signal sequence and first nine amino acids of the mature LPp) and amino acids 46-159 of OmpA. The Lpp domain localizes the tribrid to the outer membrane and stabilizes it there and the OmpA segment serves to facilitate expression of the soluble protein domain on the outer surface. Here we have produced a plasmid encoding an LppOmpAFepB tribrid. This construct was employed to determine if $\mathrm{FepB}$ does bind FeEnt and if the LppOmpA localization vehicle is applicable to periplasmic binding proteins.

\section{METHODS}

Bacterial strains and growth conditions. The bacteria used were Escherichia coli $\mathrm{K} 12$ derivatives and are described in Table 1. AB1515 is wild-type for Ent-mediated iron transport, UT5600 is unable to synthesize, bind or transport Ent, and SB221, with its defective major lipoprotein, was used as a control in leakiness assays. Strains were routinely grown in L broth (Nagel de Zwaig \& Luria, 1967) at $37^{\circ} \mathrm{C}$ with aeration. Minimal medium was M9 (Miller, 1972) supplemented as necessary as before (Pierce \& Earhart, 1986); when required, L broth was made iron-deficient by adding 2,2'-dipyridyl (Sigma) to $0.2 \mathrm{mM}$. Deferrated M9 was prepared by hydroxyquinoline extraction. Growth of liquid cultures was monitored by optical density readings at $540 \mathrm{~nm}$. When appropriate, kanamycin and IPTG were added to final concentrations of $150 \mu \mathrm{g} \mathrm{ml}^{-1}$ and $1 \mathrm{mM}$, respectively, unless otherwise indicated.

Plasmids. Plasmids are listed in Table 1. pME28 is a pGEM-3 derivative containing a lac $Z-f e p B$ fusion (Elkins \& Earhart, 1989). pTX215 and pTX600 are both derivatives of pTX210 (Francisco et al., 1993b), a plasmid encoding the tribrid protein LppOmpACBD (cellulose-binding domain). To construct pTX215, pTX210 was digested with BamHI and the larger fragment, which encodes the signal sequence and the first nine $\mathrm{N}$-terminal amino acids of Lpp, amino acids 46-159 of OmpA and a 13 amino acid segment with the sequence GINSSSVPCDPPT, was religated (C. Stathopoulos, unpublished results). In pTX600, the CBD of pTX210 was replaced with the $p h o A$ cassette of pSWF11 (Ehrmann et al., 1990) by ligation of Bam HI fragments (C. Stathopoulos, unpublished results). pTX700, which encodes a LppOmpAFepB fusion protein, is a derivative of pTX600 (Fig. 1); standard recombinant DNA techniques (Maniatis et al., 1982) were used to replace the $p h o A$ sequence of pTX 600 with the mature $f e p B$ sequence of pME28. Competent JM109 cells were transformed by electroporation; plasmids were then isolated from transformant colonies and screened by restriction mapping. All recombinants that had the desired $1.5 \mathrm{~kb}$ HindIII-BstXI fragment (containing the mature $f e p B$ sequence and part of orf 43 , a gene encoding a cytoplasmic membrane protein of unknown function) also had the $1 \cdot 1 \mathrm{~kb}$ BstXI-BstXI fragment, which contains the missing portion of orf43 (Fig. 1). Therefore pTX700 encodes not only the LppOmpAFepB fusion protein but also the product of orf43 (P43).

General procedures. Total membrane fractions were isolated by the procedure of Inouye \& Guthrie (1969); treatment of this membrane preparation with sodium lauryl sarcosinate yielded outer membrane (Filip et al., 1973). Fractionation of cell membranes was also accomplished using isopycnic sucrose density gradients (Osborn et al., 1972). SDS-PAGE (Lugtenberg et al., 1975) and Western blot procedures (Staab \& Earhart, 1990) have been described. Gels (11\%, w/v) were loaded with $20 \mu \mathrm{g}$ protein per well. Prestained protein molecular mass standards, high range (GibcoBRL), were used and when appropriate gels were stained with Coomassie brilliant blue $\mathrm{G}$. Anti-OmpA antibodies were provided by U. Henning and Y. Stierhof, Max Planck Institut für Biologie, Tübingen, Germany. Protein concentrations were determined by the procedure of Bradford (1976). 
Table 1. Bacterial strains and plasmids

\begin{tabular}{|c|c|c|}
\hline Strain or plasmid & Genotype or relevant characteristics & Source or reference \\
\hline \multicolumn{3}{|l|}{ E. coli $\mathrm{K} 12$ strain } \\
\hline AB1515 & $\begin{array}{l}\text { purE42 proC14 leu-6 trpE38 thi-1 fbuA23 lacY1 mtl-1 xyl-5 rpsL109 } \\
\text { a₹i-6 tsx-67 }\end{array}$ & CGSC* \\
\hline UT5600 & $\begin{array}{l}\text { ent } A 403 \text { purE } E^{+} \text {fbu } A^{+} \Delta(o m p T \text { env } Y \text { ent } D \text { fep } A \text { fes ent } F \text { fepE }) \text { derivative } \\
\text { of } \mathrm{AB} 1515\end{array}$ & Elish et al. (1988) \\
\hline JM109 & $\begin{array}{l}\operatorname{rec} A 1 \text { supE44 end } A 1 \text { bsd } \mathrm{R} 17 \text { gyr } A 96 \text { rel } A 1 \text { thi } \Delta(\text { lac-pro } A B) \mathrm{F}^{\prime}(\operatorname{traD} 36 \\
\left.\operatorname{pro} A B^{+} \text {lac } I^{q} \text { lac } Z \Delta M 15\right)\end{array}$ & Yanisch-Perron et al. (1985) \\
\hline SB221 & lpp bsdR $\operatorname{trpE} 5$ leuB6 lac $Y \operatorname{rec} A 1 \mathrm{~F}^{\prime}\left(\operatorname{lacI}^{q} \mathrm{lac}^{+}\right.$pro $\left.0^{+}\right)$ & Nakamura et al. (1982) \\
\hline \multicolumn{3}{|l|}{ Plasmids } \\
\hline pTX600 & $\begin{array}{l}\text { A derivative of pTX210 (Francisco et al., 1993b) in which the } \\
\text { cellulose-binding domain was replaced with the } p h o A \text { cassette of } \\
\text { pSWFII (Ehrmann } \text { et al., 1990) }\end{array}$ & C. Stathopoulos (this lab.) \\
\hline pTX215 & $\begin{array}{l}\text { A derivative of pTX } 210 \text { created by } \mathrm{BamHI} \text { digestion of pTX } 210 \text { and } \\
\text { religation of the large fragment; it encodes a LppOmpA hybrid } \\
\text { protein consisting of the signal sequence and first nine amino acids of } \\
\text { Lpp, amino acids } 46-159 \text { of OmpA and a } 13 \text { amino acid sequence }\end{array}$ & C. Stathopoulos (this lab.) \\
\hline pME28 & pGEM-3 Blue derivative containing a lac $Z-f e p B$ fusion & Elkins \& Earhart (1989) \\
\hline pTX700 & $\begin{array}{l}\text { Derivative of pTX } 600 \text { in which } p h o A \text { has been replaced by a } 2.6 \mathrm{~kb} \\
\text { fragment encoding mature FepB and P } 43 \text {, the product of orf } 43\end{array}$ & This work \\
\hline
\end{tabular}

* CGSC Coli Genetic Stock Center, Yale University, New Haven, CT, USA.

\begin{abstract}
${ }^{55}$ FeEnt binding assays. FeEnt was provided by M. Ammerlaan and F. Hantash, both at the University of Texas at Austin. ${ }^{55} \mathrm{FeCl}_{3}$ was purchased from New England Nuclear/DuPont and membrane filters (GA-6, $0.45 \mu \mathrm{m}$ pore size) were obtained from Gelman. ${ }^{55} \mathrm{FeEnt}$ was prepared by diluting $20 \mu \mathrm{l} 1 \mathrm{mM}$ FeEnt with $165 \mu \mathrm{l}$ water, adding $18 \mu \mathrm{l} 1 \mathrm{M} \mathrm{HCl}$, and extracting three times with $180 \mu$ l ethyl acetate. The ethyl acetate layers (containing free Ent) were combined, layered on $1 \mathrm{ml}$ deferrated M9 minimal medium supplemented to $100 \mu \mathrm{M}$ with nitrilotriacetic acid (M9+NTA) and containing $10 \mu \mathrm{M}^{55} \mathrm{FeCl}_{3}$, and then evaporated by air current. The resulting aqueous ${ }^{55} \mathrm{FeEnt}$ solution was diluted to $5 \mathrm{ml}$ with $\mathrm{M} 9+\mathrm{NTA}$ and passed through a Gelman filter. The final concentration was $2 \mu \mathrm{M}$ ${ }^{55} \mathrm{FeEnt}\left[6.14 \mathrm{mCi}(227 \mathrm{MBq}) \mu \mathrm{mol}^{-1}, 12 \cdot 3 \mu \mathrm{Ci}(455 \mathrm{kBq}) \mathrm{ml}^{-1}\right]$.

Whole-cell binding assays were performed essentially like uptake assays (Chenault \& Earhart, 1991), with the exception that cells were washed twice with M9+NTA before being resuspended to $\mathrm{OD}_{540} 0 \cdot 8$ in $\mathrm{M} 9+\mathrm{N} T A$. When indicated, freshly prepared $\mathrm{NaN}_{3}$ was added to $30 \mathrm{mM}$ (Pickett \& Earhart, 1981). The cell membrane binding assay was a modification of that of Ichihara \& Mizushima (1977): $250 \mu \mathrm{l}$ of $2 \mu \mathrm{M}{ }^{55} \mathrm{FeEnt}$ were combined with an equal volume of a known amount of membrane (prewarmed to $37^{\circ} \mathrm{C}$ ), incubated for $5 \mathrm{~min}$ and passed through a Gelman filter; the filter was rinsed twice with $5 \mathrm{ml}$ deferrated M9, dried under a heat lamp, and its radioactivity measured in a Beckman LS 3801 scintillation counter.
\end{abstract}

All ${ }^{55} \mathrm{FeEnt}$ binding assays were performed four times; representative results are shown in Figs 3, 4 and 5.

Assays for membrane integrity. The periplasmic leakiness assay of Lopes et al. (1972), which measures the spontaneous release of periplasmic enzyme RNase I, was used. The disc agar diffusion method, conducted on LB-agar plates, was employed to test sensitivity to SDS $(2 \%, w / v)$, Sarkosyl $(2 \%, w / v)$, deoxycholate $(2 \%, \mathrm{w} / \mathrm{v})$, rifampicin $\left(1 \mathrm{mg} \mathrm{ml}^{-1}\right)$, and lysozyme $\left(1 \mathrm{mg} \mathrm{ml}^{-1}\right)$. Accessibility of membrane proteins to trypsin degradation was assayed as described by Tommassen \& Lugtenberg (1984).

\section{RESULTS \\ pTX700 encodes an Lpp-OmpA-FepB tribrid protein}

pTX700 was constructed as described in Methods. The BstXI-generated end of PTX600 hydrogen-bonds at three of four and two of four positions to the 2.6 and $1.5 \mathrm{~kb}$ HindIII-BstXI fragments of pME28, respectively, which probably explains the fact that only the $2.6 \mathrm{~kb}$ fragment was found in recombinant plasmids (Fig. 1). Fig. 1(b) presents the DNA sequence joining the $\operatorname{mop} A$ and $f e p B$ fragments and shows that the linkage is in-frame. Sequencing was carried out using the dideoxynucleotide chain-termination method (Sanger et al., 1977).

The FepB segment of the tribrid begins with amino acid 25 of proFepB (Fig. 1b). The position at which signal peptidase cleaves proFepB is uncertain; three possible sites, after amino acids 22, 23 and 26 of proFepB, are present (Elkins \& Earhart, 1989). Therefore, the tribrid lacks at most two amino acids of mature FepB. We assume that the Lpp signal sequence is cleaved and that normal modifications of the N-terminal cysteine of the Lpp domain occur (Francisco et al., 1992; Ghrayeb \& Inouye, 1984); the calculated molecular mass for the protein part of the tribrid lipoprotein is $46416 \mathrm{Da}$.

The expression of LppOmpAFepB encoded by pTX700 is controlled both by the $l p p$ promoter and the lac promoter-operator region. Preliminary growth experi- 
(a)

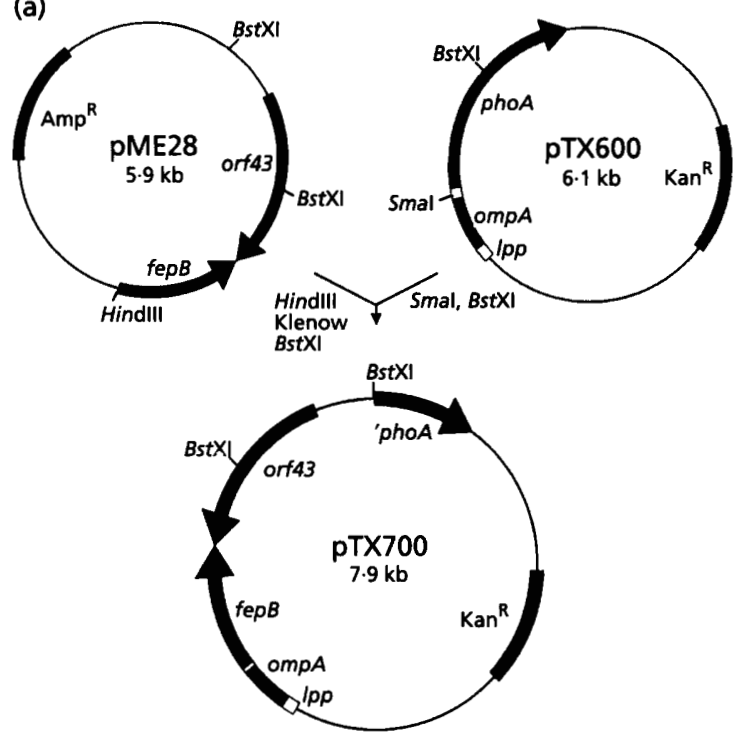

(b)

$$
\text { a.a. } 159 \text { of OmpA }
$$

AACGGAATTAATTCGAGCTCGGTACCCAGCTTGCAG

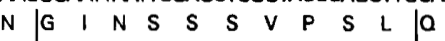

Linker

Fig. 1. (a) Construction of pTX700. The 836 bp Smal-BstXI fragment in pTX600 was replaced by the $2.6 \mathrm{~kb}$ BstXI-HindlII fragment from pME28 to yield pTX700. (b) Deoxynucleotide sequence and deduced amino acid sequence of the ompA-fepB junction in pTX700. Shown are the last amino acid of the OmpA segment, the first amino acid of the FepB segment, and the connecting linker.

ments determined that addition of IPTG $(1 \mathrm{mM})$ to midexponential-phase UT5600/pTX700 cells growing at $37^{\circ} \mathrm{C}$ in $\mathrm{L}$ broth resulted in a decrease in growth rate after $30 \mathrm{~min}$, suggesting that under these conditions tribrid protein synthesis is deleterious to growth, presumably because of alterations in membrane architecture and function. In attempts to observe the tribrid protein, an induction time of $30 \mathrm{~min}$ and a variety of IPTG concentrations were used (Fig. 2). IPTG concentrations ranging from $100 \mu \mathrm{M}$ to $1 \mathrm{mM}$ gave similar results and the protein profiles of total membrane preparations from UT5600 and UT5600/pTX700 were similar in the absence of IPTG (data not shown). Upon induction with IPTG, two distinct new protein bands with molecular masses of 37 and $42 \mathrm{kDa}$ were observed (Fig. 2a, lane 3). In stained gels of purified outer membrane, four new bands (46.5, 44, 42 and $37 \mathrm{kDa}$ ) were seen (data not shown). The $44 \mathrm{kDa}$ polypeptide band may be present but partially obscured by a normal membrane protein in Fig. 2(a). When a similar gel was examined by Western blotting procedures employing anti-OmpA antibodies, at least five new proteins with molecular masses greater than OmpA were seen (Fig. 2b). (The bands corresponding to OmpA and the smallest polypeptide $(27 \mathrm{kDa})$ in Fig. 2(b) were absent when similar Western blot analyses were performed on a strain deleted from $o m p A$ : data not shown.) The five new proteins must be tribrid-related; each had an OmpA domain, the Lpp domain was inferred because in its

(a)

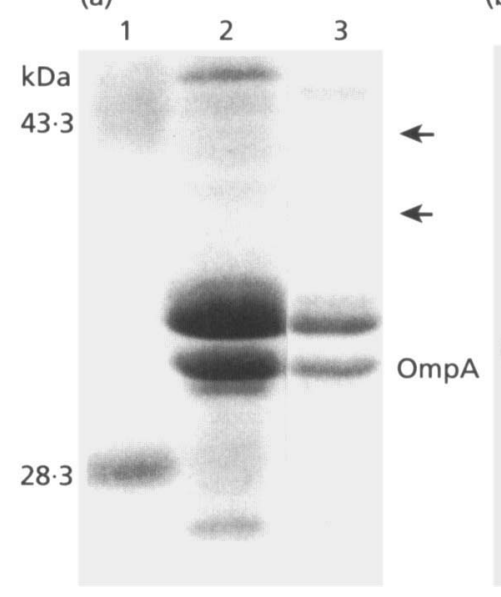

(b)

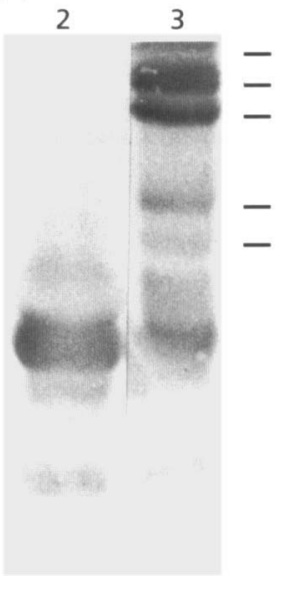

Fig. 2. Induction of the LppOmpAFepB tribrid. Total membranes were isolated from UT5600 and UT5600/pTX700 cultures grown at $37^{\circ} \mathrm{C}$ in $\mathrm{LB}$ and, at $O \mathrm{D}_{540} 0.5$, induced for 30 min with $1 \mathrm{mM}$ IPTG. (a) Separation of membrane proteins by SDS-PAGE; proteins were stained with Coomassie brilliant blue. Arrows indicate bands corresponding to proteins whose presence is dependent on pTX700 (see b). Lane 1, prestained molecular mass standards ovalbumin $(43.3 \mathrm{kDa})$ and carbonic anhydrase (28.3 kDa); lane 2, UT5600; lane 3, UT5600/pTX700 induced with IPTG. (b) Western blot of lanes 2 and 3 of (a) in which OmpA antiserum provided the primary antibodies. Horizontal lines indicate bands arising from the presence of pTX700.

absence the protein would not be in the outer membrane (see below), and some FepB sequence must have been present to account for the molecular masses of the bands. Two of these bands ( 42 and $44 \mathrm{kDa}$ ) were evident even in uninduced UT5600/pTX700 cells (data not shown). Upon induction, all five bands were evident and in approximately the same relative abundance regardless of IPTG concentration. The two smallest bands 37 and $35.5 \mathrm{kDa}$ ) are likely to be proteolysis products but the nature of the three largest LppOmpAFepB related bands is unclear. Mature FepB appears as multiple bands in polyacrylamide gels (Pierce \& Earhart, 1986) and this unusual electrophoretic behaviour requires that FepB have an intact carboxy terminus (Elkins \& Earhart, 1989); this obtains for the FepB domains of the tribrid.

Additional experiments disclosed that the amount of tribrid in membrane increased steadily with increasing time of induction. When localization studies were performed on cells that had been induced for more than $30 \mathrm{~min}$, the tribrid was found in both inner and outer membrane. In contrast, at short ( $30 \mathrm{~min})$ induction times, the tribrid was located primarily in the outer membrane (data not shown).

\section{Membranes from UT5600/pTX700 cells bind FeEnt}

FepA, the outer membrane receptor for FeEnt, is absent in UT5600 and FeEnt binding to membrane from similar strains is at the background level (McIntosh et al., 1979). Therefore, if membrane from UT5600/pTX700 bound 


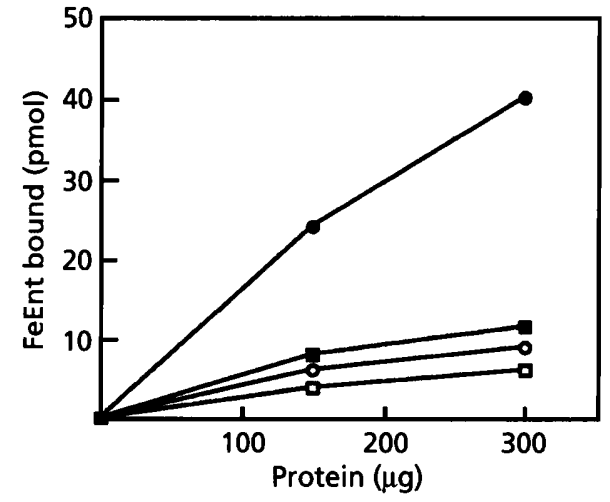

Fig. 3. Binding of ${ }^{55} \mathrm{FeEnt}$ to membranes from UT5600 and UT5600/pTX700 cells. O. UT5600/pTX700 outer membrane; $\square$, UT5600/pTX700 inner membrane; $O$, UT5600 outer membrane; $\square$, UT5600 inner membrane.

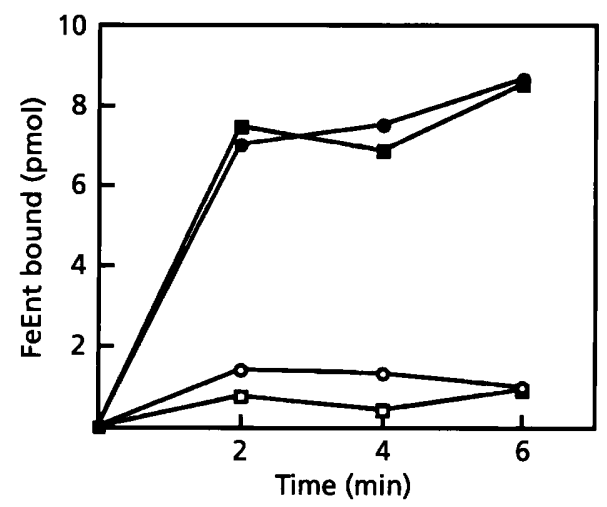

\begin{tabular}{|c|c|c|}
\hline $\begin{array}{l}\text { Fig. 4. Binding of } \\
\text { UT5600/pTX215 cells. } \\
\text { UT5600/pTX700+ } \mathrm{NaN}_{3} \text {. } \\
\text { UT5600/pTX215+ } \mathrm{NaN}_{3} \text {. }\end{array}$ & $\begin{array}{c}{ }^{55} \mathrm{FeEnt} \\
\square . \\
\square .\end{array}$ & $\begin{array}{c}\text { by UT5600/pTX700 } \\
\text { UT5600/pTX700; } \\
\text { UT5600/pTX215; }\end{array}$ \\
\hline
\end{tabular}

FeEnt, this would indicate that FepB is a FeEnt-binding protein. This was the case (Fig. 3); outer membrane from cells harbouring pTX700 bound four times more FeEnt than outer membrane from UT5600. The binding to outer membrane from UT5600 and to inner membrane is believed to be adventitious. In the cytoplasmic membrane, there is no known protein capable of binding FeEnt unaided ; also, FeEnt transport proteins are repressed in $\mathrm{L}$ broth. Outer membrane isolated by the Sarkosyl procedure gave results similar to those shown in Fig. 3. These data demonstrate that FepB does have the ability to bind FeEnt.

\section{Cells expressing LppOmpAFepB tribrid protein bind FeEnt}

The LppOmpA vector is believed to position the carboxyterminal soluble protein on the cell surface (Francisco et al., 1992). If this is true for the LppOmpAFepB construct, whole-cell binding assays should be feasible. These were performed; they were conducted similarly to FeEnt

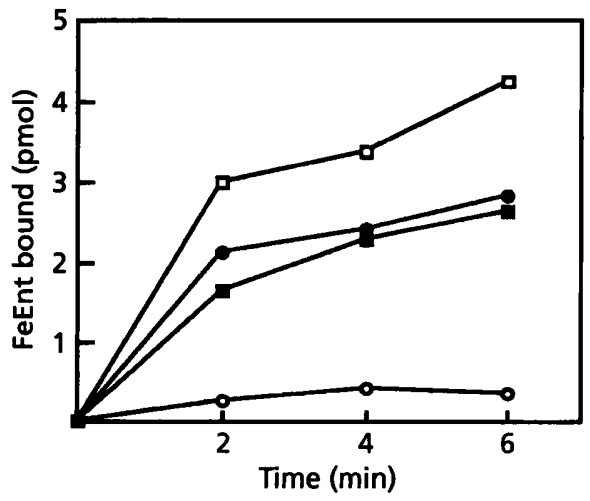

Fig. 5. Association of ${ }^{55} \mathrm{FeEnt}$ with $A B 1515$ and UT5600/pTX700 cells grown in iron-deficient (LB plus dipyridyl) medium. $\square$, AB1515; O, AB1515 $+\mathrm{NaN}_{3} ; \square$, UT5600/pTX700 UT5600/pTX700+ $\mathrm{NaN}_{3}$.

uptake assays. For FeEnt binding to surface-exposed FepB, however, it was anticipated that FeEnt would not be taken up into cells. To verify that binding and not uptake was being measured, $\mathrm{NaN}_{3}$, which is known to prevent cellular uptake of FeEnt (Pickett \& Earhart, 1981), was added to some samples. As shown in Fig. 4, UT5600/pTX700 cells bound FeEnt and this binding was energy-independent. UT5600/pTX215 cells had only basal level binding of FeEnt; UT5600 and uninduced UT5600/pTX700 cells gave results similar to UT5600/pTX215 cells (data not shown). To distinguish between FeEnt binding and uptake, the ability of FeEnt to associate with $\mathrm{AB} 1515\left(\mathrm{fep} A^{+}\right)$cells starved for iron by growth in LB plus dipyridyl medium was also assayed. As seen in Fig. 5, azide reduced the amount of AB1515associated FeEnt. Similar results were obtained when cultures were grown in deferrated M9 medium. That is, FeEnt association with AB1515 resulted mainly from uptake, not binding. Results with UT5600/pTX700 serve to further emphasize the distinction between binding and uptake and, when compared to Fig. 4, to illustrate the dayto-day variation in c.p.m. bound observed in these wholecell binding experiments.

\section{Effect of the tribrid on outer membrane permeability}

The ability of FeEnt to bind to UT5600/pTX700 cells does not prove that the FepB segment of the tribrid is located on the outer surface. Perturbation of the outer membrane resulting from insertion of the tribrid protein might permit FeEnt to partially penetrate or to completely pass through the outer membrane and to enter the periplasmic space. (Under normal conditions, FeEnt is barely too large to be accommodated by the outer membrane general porins, which exclude solutes of molecular mass $>600 \mathrm{Da}$ : Nikaido, 1992). Several assays were employed to determine if the pTX700-encoded tribrid influenced outer membrane permeability.

The sensitivities of UT5600 and UT5600/pTX700 cells to detergents, rifampicin and lysozyme were similar (data not shown). In the periplasmic leakiness assay, UT5600, 


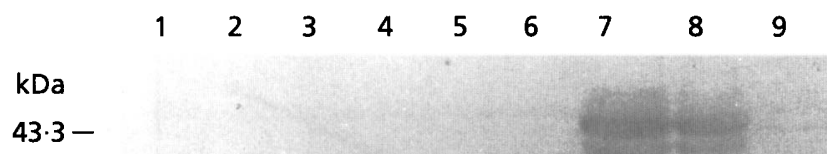

$28 \cdot 3-$
Fig. 6. Sensitivity of total membrane proteins to trypsin. Growth, electrophoresis and Western blotting were as described for Fig. 2. Horizontal lines on the left indicate the positions of $43.3 \mathrm{kDa}$ and $28.3 \mathrm{kDa}$ standards. UT5600 (Lanes 1-3), UT5600/pTX215 (lanes 4-6) and UT5600/pTX700 (lanes 7-9) are shown. Incubation conditions were: Tris only (lanes 1, 4 and 7); Tris-Mg(II) + trypsin (lanes 2, 5 and 8) and Tris-EDTA + trypsin (lanes 3, 6 and 9).

UT5600/pTX215 and UT5600/pTX700 all displayed haloes $1 \mathrm{~mm}$ in width surrounding individual colonies. The halo was turbid for UT5600, intermediate in turbidity for UT5600/pTX215, and clear for UT5600/pTX700. Colonies of control strain SB221, which is leaky because of the lpp mutation, exhibited clear haloes $2 \mathrm{~mm}$ in width.

Because long-term induction of the tribrid protein is lethal, the above plate assays had to be conducted with uninduced cells. To study permeability under conditions more closely resembling those used in the binding studies, the accessibility of membrane proteins of UT5600, UT5600/pTX215 (induced) and UT5600/pTX700 (induced) to trypsin was examined. On the gels used, the LppOmpA dibrid encoded by p TX 215 was too small to be resolved. Monitoring of OmpA and its $24 \mathrm{kDa}$ trypsin degradation product (Fig. 6), which is believed to arise from digestion of the OmpA periplasmic tail, demonstrated that Tris-EDTA-trypsin treatment resulted in complete elimination of mature OmpA in all three strains. However, under intermediate conditions for trypsin activity [Tris- $\mathrm{Mg}$ (II)-trypsin], OmpA in UT5600 was more resistant than the OmpA of UT5600/pTX215, which in turn was more resistant than that of UT5600/pTX700. This was the same order of sensitivity as revealed by the periplasmic RNase leakiness assay. The tribrid protein and its degradation products were like OmpA in that they were not completely eliminated until the more rigorous digestion conditions were used.

\section{DISCUSSION}

Unlike most periplasmic binding proteins, those specific for ferrisiderophore complexes are not easy to assay. Here FepB was incorporated as the carboxy-terminal segment of a tribrid fusion protein that was localized in the membrane. The presence of the chimaeric protein conferred on the outer membrane the ability to bind FeEnt. The possibility that insertion of the tribrid had indirect effects on membrane architecture that led to increased binding to outer membrane preparations by FeEnt, for example by exposing FeEnt binding sites of other membrane proteins, seems remote. FepA is absent in UT5600 and FecA, the only other membrane protein reported to bind FeEnt (Zhou et al., 1993; Zhou \& van der Helm, 1993) is not induced under the conditions used and binds FeEnt with approximately 10 -fold less affinity than FepA (D. van der Helm, personal communication). We conclude that (i) membrane binding assays involving the LppOmpAFepB construct are as valid as those for normal outer membrane ferrisiderophore receptors and (ii) that the FepB domain of the tribrid was responsible for the binding of FeEnt to outer membrane from UT5600/pTX700. That normal FepB activity was not abolished by the LppOmpA sequence is consistent with results obtained with other LppOmpA-based tribrids (Francisco et al., 1992, 1993a, b).

UT5600/pTX700 cells bound FeEnt, providing additional evidence for the specificity of FepB towards FeEnt. A consideration in these experiments is the possibility that tribrid insertion increases the outer membrane permeability of cells, allowing unaided transmembrane passage of FeEnt into the periplasm, where it could be bound by normal FepB. Subsequent events would depend on whether or not UT5600 is fepD $D^{+} G^{+}$, which is not known (Elish et al., 1988). If periplasmic FepB could bind FeEnt in UT5600/pTX700 and if entry into the cytoplasm were impossible due to a defective cytoplasmic membrane permease, FeEnt-FepB could accumulate in the periplasm. This would then be similar to a system employed to demonstrate $\mathrm{Fe}$ (III)hydroxamate siderophore binding to FhuD (Koster \& Braun, 1990). In this previous case, however, overexpression of FhuD was necessary to demonstrate ferrisiderophore-FhuD association; here (Fig. 4), it is unlikely that periplasmic FepB in UT5600/pTX700 bound detectable amount of FeEnt as only minimal (repressed) levels of FepB were available. Transport of FeEnt into the cytoplasm of UT5600/pTX700 cells, which would be feasible if UT5600 cells are $f e p C^{+} D^{+} G^{+}$ and if UT5600/pTX700 cells were leaky, would require energy and did not occur (Figs 4 and 5).

Some loss of outer membrane integrity occurred upon induction of LppOmpAFepB synthesis. This complicated efforts aimed at determining the orientation of $\mathrm{FepB}$ in the outer membrane. At least some of the tribrid FepB may be directed toward the periplasm rather than the external milieu. The trypsin accessibility studies, which showed that the tribrid and periplasmic OmpA tail exhibited similar sensitivities, were repeated using several digestion conditions but no preferential degradation of the tribrid was observed. With previous LppOmpA chimaeras, surface exposure of the passenger domain was monitored using immunological techniques, such as immunofluorescence and whole-cell ELISA assays; in the absence 
of anti-FepB antibodies, these techniques were unavailable here. For establishing that FepB binds FeEnt, the major finding of this work, the outer membrane orientation of FepB was unimportant and additional experiments to test cell permeability and to determine tribrid topology were not performed for this study.

The origin(s) of the multiple LppOmpAFepB bands is unclear and the band(s) which bind FeEnt are unknown. It is not unusual for LppOmpA-based tribrids to be subjected to significant proteolysis (Francisco et al., 1992, $1993 \mathrm{~b}$ ) and some of the bands must have arisen in this manner. However, the three largest bands $(42-46.5 \mathrm{kDa}$ range: Fig. $2 \mathrm{~b}$ ) are similar in pattern and intensity to those seen when $f e p B$ alone is expressed in mini- and maxicells (Elkins \& Earhart, 1989; Ozenberger et al., 1987; Pierce \& Earhart, 1986). If the several large tribrid bands do originate from peculiarities of FepB, this work, in which they were detected immunologically, would mark the first time the bands had been observed in other than mini- or maxi-cells.

In summary, we have shown that the FepB protein bound FeEnt and that the LppOmpA localization vehicle can be employed for periplasmic binding proteins.

\section{ACKNOWLEDGEMENTS}

We thank M. Ammerlaan and F. Hantash for gifts of enterobactin, $H$. Poetschke for DNA sequencing, C. Stathopoulos for providing pTX600 and pTX215, and U. Henning and Y. Stierhof for OmpA antiserum.

This work was supported by Public Health Service grant GM47885 from the National Institutes of Health and NSF grant 9212305 to C.F.E. M.D.C. was supported in part by Howard Hughes Molecular Biology Institute funds.

\section{REFERENCES}

Ames, G. F.-L. (1986). Bacterial periplasmic transport systems: structure, mechanism, and evolution. Annu Rev Biochem 55, 397-425.

Bradford, M. M. (1976). A rapid and sensitive method for the quantitation of microgram quantities of protein utilizing the principle of protein-dye binding. Anal Biochem 72, 248-254.

Chenault, S.S. \& Earhart, C. F. (1991). Organization of genes encoding membrane proteins of the Escherichia coli ferrienterobactin permease. Mol Microbiol 5, 1405-1413.

Chenault, S. S. \& Earhart, C. F. (1992). Identification of hydrophobic proteins FepD and FepG of the Escherichia coli ferrienterobactin permease. J Gen Microbiol 138, 2167-2171.

Earhart, C. F. (1987). Ferrienterobactin transport in Escherichia coli. In Iron Transport in Microbes, Plants and Animals, pp. 67-84. Edited by G. Winkelmann, D. van der Helm \& J. B. Neilands. Weinheim: VCH Verlagsgesellschaft.

Ehrmann, M., Boyd, D. \& Beckwith, J. (1990). Genetic analysis of membrane protein topology by a sandwich gene fusion approach. Proc Natl Acad Sci US A 87, 7574-7578.

Elish, M. E., Pierce, J. R. \& Earhart, C. F. (1988). Biochemical analysis of spontaneous fep $A$ mutants of Escherichia coli. $J$ Gen Microbiol 134, 1355-1364.

Elkins, M. F. \& Earhart, C. F. (1989). Nucleotide sequence and regulation of the Escherichia coli gene for ferrienterobactin transport protein FepB. J Bacteriol 171, 5443-5451.
Fath, M. J. \& Kolter, R. (1993). ABC transporters: bacterial exporters. Microbiol Rev 57, 995-1017.

Filip, C., Fletcher, G., Wulff, J. L. \& Earhart, C. F. (1973). Solubilization of the cytoplasmic membrane of Escherichia coli by the ionic detergent sodium-lauryl sarcosinate. J Bacteriol 115, 717-722.

Francisco, J. A., Earhart, C. F. \& Georgiou, G. (1992). Transport and anchoring of $\beta$-lactamase to the external surface of Eschericbia coli. Proc Natl Acad Sci US A 89, 2713-2717.

Francisco, J. A., Campbell, R., Iverson, B. L. \& Georgiou, G. (1993a). Production and fluorescence-activated cell sorting of Escherichia coli expressing a functional antibody fragment on the external surface. Proc Natl Acad Sci US A 90, 10444-10448.

Francisco, J. A., Stathopoulos, C., Warren, R. A. J., Kilburn, D. G. \& Georgiou, G. (1993b). Specific adhesion and hydrolysis of cellulose by intact Escherichia coli expressing surface anchored cellulose binding domains. Bio/Technology 11, 491-495.

Furlong, C. E. (1987). Osmotic-shock-sensitive transport systems. In Escherichia coli and Salmonella typhimurium: Cellular and Molecular Biology, pp. 768-796. Edited by F. C. Neidhardt, J. L. Ingraham, K. B. Low, B. Magasanik, M. Schaechter \& H. E. Umbarger. Washington, DC: American Society for Microbiology.

Ghrayeb, J. \& Inouye, M. (1984). Nine amino acid residues at the $\mathrm{NH}_{2}$-terminal of lipoprotein are sufficient for its modification, processing, and localization in the outer membrane of Escherichia coli. J Biol Chem 259, 463-467.

Guyer, C. A., Morgan, D. G., Osheroff, N. \& Staros, J. V. (1985). Purification and characterization of a periplasmic oligopeptide binding protein from Escherichia coli. J Biol Chem 260, 10812-10818.

Ichihara, S. \& Mizushima, S. (1977). Involvement of outer membrane proteins in enterochelin-mediated iron uptake in Escherichia coli. J Biochem 81, 749-756.

Inouye, M. \& Guthrie, J. P. (1969). A mutant which changes a membrane protein of E. coli. Proc Natl Acad Sci US A 64, 957-961.

Koster, W. \& Braun, V. (1990). Iron(III) hydroxamate transport into Escherichia coli. Substrate binding to the periplasmic proteins. $J$ Biol Chem 265, 21407-21410.

Lever, J. E. (1972). Quantitative assay of the binding of small molecules to protein: comparison of dialysis and membrane filter assays. Anal Biochem 50, 73-83.

Lopes, J., Gottfried, S. \& Rothfield, L. (1972). Leakage of periplasmic enzymes by mutants of Escherichia coli and Salmonella typhimurium: isolation of 'periplasmic leaky' mutants. $J$ Bacteriol $109,520-525$.

Lugtenberg, B., Meyers, J., Peters, R., van der Hoek, P. \& van Alphen, L. (1975). Electrophoretic resolution of the 'major outer membrane protein' of Escherichia coli $\mathrm{K} 12$ into four bands. FEBS Lett 58, 254-258.

Mcintosh, M. A., Chenault, S. S. \& Earhart, C. F. (1979). Genetic and physiological studies on the relationship between colicin B resistance and ferrienterochelin uptake in Escherichia coli K-12. $J$ Bacteriol 137, 653-657.

Maniatis, T., Fritsch, E. F. \& Sambrook, J. (1982). Molecular Cloning : a Laboratory Manual. Cold Spring Harbor, NY: Cold Spring Harbor Laboratory.

Miller, J. H. (1972). Experiments in Molecular Genetics, p. 431. Cold Spring Harbor, NY: Cold Spring Harbor Laboratory.

Nagel de Zwaig, R. \& Luria, S. E. (1967). Genetics and physiology of colicin-tolerant mutants of Escherichia coli. J Bacteriol 94, 1112-1123.

Nakamura, K., Masui, Y. \& Inouye, M. (1982). Use of a lac promoter-operator fragment as a transcriptional control switch for 
expression of the constitutive lpp gene in Escherichia coli. J Mol Appl Genet 1, 289-299.

Nikaido, H. (1992). Porins and specific channels of bacterial outer membranes. Mol Microbiol 6, 435-442.

Osborn, M. J., Gander, J. E., Parisi, E. \& Carson, J. (1972). Mechanism of assembly of the outer membrane of Salmonella typhimurium. J Biol Chem 247, 3962-3972.

Ozenberger, B. A., Nahlik, M. S. \& McIntosh, M. A. (1987). Genetic organization of multiple fep genes encoding ferric enterobactin transport functions in Escherichia coli. J Bacteriol 169, 3638-3646.

Pickett, C. L. \& Earhart, C. F. (1981). Iron uptake in pseudorevertants of Escherichia coli K-12 mutants with multiple defects in the enterochelin system. Arch Microbiol 128, 360-364.

Pierce, J. R. \& Earhart, C. F. (1986). Escherichia coli K-12 envelope proteins specifically required for ferrienterobactin uptake. J Bacteriol 166, 930-936.

Postle, K. (1993). TonB protein and energy transduction between membranes. J Bioenerg Biomembr 25, 591-601.

Quiocho, F. A. (1990). Atomic structures of periplasmic binding proteins and the high-affinity active transport systems in bacteria. Phil Trans R Soc Lond 326, 341-351.

Rosen, B. P. \& Vasington, F. D. (1971). Purification and characterization of a histidine-binding protein from Salmonella typhimurium LT-2 and its relationship to the histidine permease system. $J$ Biol Chem 246, 5351-5360.

Rutz, J. M., Liu, J., Lyons, J. A., Goranson, J., Armstrong, S. K., McIntosh, M. A., Feix, J. B. \& Klebba, P. E. (1992). Formation of a gated channel by a ligand-specific transport protein in the bacterial outer membrane. Science 258, 471-475.

Sanger, F., Nicklen, S. \& Coulson, A. R. (1977). DNA sequencing with chain-terminating inhibitors. Proc Natl Acad Sci USA 74, 5463-5467.

Shea, C. M. \& Mclntosh, M. A. (1991). Nucleotide sequence and genetic organization of the ferric enterobactin transport system: homology to other periplasmic binding protein-dependent systems in Escherichia coli. Mol Microbiol 5, 1415-1428.

Silver, S. \& Walderhaug, M. (1992). Gene regulation of plasmidand chromosome-determined inorganic ion transport in bacteria. Microbiol Rev 56, 195-228.

Staab, J. F. \& Earhart, C. F. (1990). EntG activity of Escherichia coli enterobactin synthetase. J Bacteriol 172, 6403-6410.

Stoebner, J. A., Butterton, J. R., Calderwood, S. B. \& Payne, S. M. (1992). Identification of the vibriobactin receptor of Vibrio cholerae. $J$ Bacteriol 174, 3270-3274.

Tommassen, J. \& Lugtenberg, B. (1984). Amino terminus of outer membrane PhoE protein: localization by use of a bla-phoE hybrid gene. J Bacteriol 157, 327-329.

Yanisch-Perron, C., Vieira, J. \& Messing, J. (1985). Improved M13 phage vectors and host strains: nucleotide sequences of the M13mp18 and pUC19 vectors. Gene 33, 103-119.

Zhou, X. H. \& van der Helm, D. (1993). A novel purification of ferric citrate receptor (FecA) from Escherichia coli UT5600 and further characterization of its binding activity. BioMetals 6, 37-44.

Zhou, X. H., van der Helm, D. \& Adjimani, J. (1993). Purification of outer membrane iron transport receptors from Escherichia coli by fast protein liquid chromatography: FepA and FecA. BioMetals 6, 25-35.

Received 3 March 1995; accepted 14 March 1995. 